\title{
THE CORRELATION BETWEEN ENGLISH DEPARTMENT STUDENTS' HABIT IN WATCHING ENGLISH MOVIES AND THEIR VOCABULARY KNOWLEDGE
}

\author{
Uena Apulisa \\ uenaapulisa@gmail.com \\ Universitas Riau, Indonesia \\ Novitri \\ novitri_11@yahoo.com \\ Universitas Riau, Indonesia \\ Masyhur \\ masyhurr20@gmail.com \\ Universitas Riau, Indonesia
}

\begin{abstract}
This research discussed the correlation between English department students' habit in watching English movies and their vocabulary knowledge. The background of conducting this research is to see how the possibility of students' habits in watching English movies influenced students' vocabulary knowledge. Furthermore, to find out if there is a significant correlation between English department students' habit in watching English movies and their vocabulary knowledge, this research determines the descriptive correlational method as the research design. After collecting and analyzing the data, it is obtained that the students' habit in watching English movies is categorized in the "high" habit category, and vocabulary knowledge is categorized in "good" ability, and significant correlation value is in moderate level correlation. In other words, it is implied that the students' habit in watching English movies was influenced to the acquisition of students' vocabulary knowledge.
\end{abstract}

Keywords: Correlation, Habit, English Movies, Vocabulary Knowledge.

\section{INTRODUCTION}

English as a global language is one of the essential languages in the world. And it is beneficial for those who learn it. If someone has an ability to use English, he has an opportunity to interact with people in the world. In Indonesia, English is the first foreign language that becomes one of the subjects that should be taught at school.
In learning English, four skills must be comprehended, they are writing, reading, listening and speaking. All of those skills are equally important as well. However, in order to master all those skills, there is an essential fundamental aspect that must be mastered first it is vocabulary. Timotius (2013) states that teaching vocabulary is 
one of the focuses of teaching English as a foreign language. It is a basic skill which should be mastered by the learners before they learn other language skills. According to David Wilkins in Thornbury (2002) stated that "without grammar, very little can be conveyed, without vocabulary, nothing can be conveyed". Hence, it is clear that learners should master vocabulary in order to learn English successfully.

Moreover, the field of education today is very closely related to the use of technology and it has a positive impact that affects the development of highly sophisticated technology in terms of education. Many kinds of media can be used to enrich students' vocabulary knowledge, such as listening to music, watching video, movie or film, etc. Films display spoken language or sounds and motion pictures that can be used to increase vocabulary knowledge. Therefore, English movies provide an excellent opportunity for learners to enrich their vocabulary. Movie is a very amuse and motivating medium for learners. Watching the movie assist learners understand the meaning of a spoken language since they can see firsthand how the situation and the expression of the actors in audio-visual form.

Furthermore, Margono (2010) said that movie is an excellent alternative media for teaching vocabulary. It is interesting since it provides audio-visual examples through the acting in the scenes. The strong point of using movies as a learning medium besides strengthening their understanding of that new vocabulary, the learners also can learn the visual image of the things that they have watched. And the learners also will remember the words, the meaning and how to use those words properly. Media such as a movie has a very significant role in motivating the learners to learn vocabulary, and they feel something new and different from what they usually experienced in their class.

Thus by using movies, learners become more interested in gaining vocabulary knowledge because they study without feeling bored. Moreover, the learning process is not only and always in the class, or face with the teacher, it can be done everywhere and any time. The habit of watching movies could provide excellent opportunities to study language about vocabulary. The learner's habit of watching English movies possibly is a way to enrich their vocabulary

Based on the explanation above, the researcher assumes that students' habit in watching English movies was influenced to the acquisition of vocabulary knowledge. Those matters make the researcher interested to discover students' habit in watching English movies and 
their vocabulary knowledge. The researcher wishes to know the students' habit in watching English movies and real score of vocabulary knowledge of the second year English department of Universitas Riau. Therefore, this study will

\section{REVIEW OF RELATED LITERATURES}

\section{a. The Nature of Habit}

Habit is a routine behavior that is repeated regularly and tends to happen without realizing it. According to Riandi (2016), habits are activities or attitudes that exist in man both physically and mentally by doing it repeatedly and in the long term. A habit is an event or experience in life that is repeated over and over, from time to time, from year to year. In line with that statement Andrew Darnton (2007) also stated that there are two perspectives on habit which are Sociology and Psychology. In Sociology, habit appears as routine practices. meanwhile, In Psychology, habit appears as a psychological construct and a factor that influences behavior.

Furthermore, Dubray concluded that with practice a habit can be acquired. therefore, repetition must be grown and strengthened in order to acquire a habit. As the statements above stated by experts, it can conclude that habit is the effect of repetitive actions that become answer a research question "Is there any significant correlation between English department students' habit in watching English movies and their vocabulary knowledge?"

patterned behaviour which has become the usual way due to frequent repetition. Moreover, the habit of watching movies has several benefits in the process of learning English, as proposed by Chayati (2019) said that movies can benefit students in a number of other ways:

- It Motivates Students: Movies display language in a lively and entertaining way. The combination of moving pictures and sound provides a more comprehensive and realistic language than other teaching medium.

- It presents language in context: Movies display conversations in a more vivid and realistic context. The complete situation was immediately apparent to the students.

- It illustrates behaviour and relationships: Movies show the difference between how people behave in formal relationships 
and how to behave in informal relationships involving friends and family.

- It presents non-verbal aspects of communication: Movies provide an overview to students about how body language, gestures, and facial expressions of the characters are shown in the film.

- It provides cultural information: Movies show how people live and how they interact with people in their own cultural environment.

\section{b. The Nature of Movie}

A movie is a real form of the development of technology that is very sophisticated in this era. Many things can be explained through movies, including about the processes that occur in our body or occur in an industry, how to live in a foreign country, the culture of a foreign country, the history of the lives of great people, and so forth. According to Aziz and Fathiyyaturrizqi (2017), the movie is a series of moving pictures recorded with the sound that tells a story.

Furthermore, Azhar (2011) defines a movie as a depiction of a work of art within a frame and mechanically projected through a projector lens so that the image on the screen appears alive. Meanwhile Blasco (2015) states the movie provides the integration of emotions in the viewing experience, and help students to understand and immediately recognize the main messages about human attitudes and values conveyed by movie characters.

Based on the definition of movie above, it can be inferred that movie is a work of humans and as a result of the times, in the form of a collection of images that move and produce sound and have a storyline. The present movie is not only included in the category of art but has entered the world of education as a practical learning media.

\section{c. The Nature of Vocabulary}

Vocabulary is defined as a set of all words understood by someone, or all words that someone might use to construct a new sentence. Vocabulary is the reality of words owned by someone who refers to certain concepts, has certain rules, and used to give and receive information. According to Nawayanti (2013), vocabulary is one of the language components which should be mastered by English learners.

Therefore vocabulary plays an important role in supporting mastery of language skills. Furthermore, Thornbury (2002) said that it is one of foreign languages that are used as a means of 
communication, and vocabulary is one of the important language elements the learner should master. The famous linguist Wilkins in Yiwei (2009) say people still could communicate each other even without grammar, but they can't express anything without vocabulary. That is,

\section{METHODS}

This research was conducted to the second year of English Department students of Universitas Riau. In this study, the population of this research was the second year English department students of Universitas Riau in academic year 2019/2020. Where the second year students consist of three classes and the population are 119 students of English department Universitas Riau. This research used cluster random sampling techniques to people can still understand what other people are saying without correct grammar rules as long as they use appropriate vocabulary. Therefore, vocabulary is an important aspect to be considered in effective communication as well.

choose the class to be the sample. Class B and $\mathrm{C}$ were selected as the sample. There are 80 students from both of the classes, and all of them were taken as the sample of this research. In conducting the research, the researcher collected the data by Questionnaire and vocabulary test. This study used Pearson Product Moment Correlation to analyze the data and the data was calculated by using SPSS 23.

\section{RESULTS AND DISCUSSION}

Based on the results of the year students of English Department can questionnaires, the habit of the second be described as follows:

Table 1 The Classifications of Students' Habit in Watching English Movies Scores

\begin{tabular}{|c|c|c|c|}
\hline Score & Classification & Frequencies & Percentage \\
\hline $84-100$ & Very High & 12 & $15 \%$ \\
\hline $68-84$ & High & 47 & $59 \%$ \\
\hline $52-68$ & Average & 21 & $26 \%$ \\
\hline $36-52$ & Low & 0 & $0 \%$ \\
\hline $20-36$ & Very Low & 0 & $0 \%$ \\
\hline \multicolumn{2}{|c|}{ TOTAL } & 80 & $100 \%$ \\
\hline
\end{tabular}


The table 1 indicates that the students' habit in watching Englis $\mathrm{h}$ movies is in a high category with the score is 69,93 . There are 12 students $(15 \%)$ obtain a very high habit in watching English movies, and 21 students $(26 \%)$ obtain an average habit in watching English movies but most of the students, (59\%) as much 47 students have obtained a high score in habit in watching English movies. Therefore, it can be concluded the habit in watching English movies is at a high level.

Table 2 The Classification of Students' Vocabulary Knowledge Scores

\begin{tabular}{|c|c|c|c|}
\hline Score & Category & Frequency & Percentage (\%) \\
\hline $80-100$ & Excellent & 10 & $12.5 \%$ \\
\hline $66-79$ & Good & 39 & $49 \%$ \\
\hline $56-65$ & Sufficient & 24 & $30 \%$ \\
\hline $40-55$ & Fairly Sufficient & 6 & $7.5 \%$ \\
\hline $0-39$ & Poor & 0 & $0 \%$ \\
\hline & TOTAL & 80 & $99 \%$ \\
\hline
\end{tabular}

Table 2 indicates the level of students' vocabulary knowledge. The number of samples is 80 . There are 10 students (12.5\%) in Excellent level, 39 students (49\%) in Good level, 24 students $(30 \%)$ in Sufficient level, 6 students
$(7.5 \%)$ in Fairly Sufficient level in vocabulary test. Therefore, it can be concluded that the vocabulary knowledge of students is mostly in Good level because the highest percentage is in Good level $(49 \%)$.

Table 3 The Statistical Scores of Students' Habit

\begin{tabular}{|c|c|c|}
\hline \multicolumn{3}{|c|}{ Statistics } \\
\hline & $\begin{array}{l}\text { Valid } \\
\text { Missing }\end{array}$ & $\begin{array}{r}80 \\
0\end{array}$ \\
\hline & & 69.9375 \\
\hline & & 70.0000 \\
\hline & & $77.00^{\mathrm{a}}$ \\
\hline & iation & 8.92209 \\
\hline & & 79.604 \\
\hline & & 37.00 \\
\hline & & 55.00 \\
\hline & & 92.00 \\
\hline $\mathrm{Su}$ & & 5595.00 \\
\hline
\end{tabular}

JEE (Journal of English Education) Vol. 7 No. 1, June 2021 
The table 3 shows the mean score of Students' Habit is 69.93. The median score is 70.00 . The mode is 77.00 . The highest score of habit is 92.00 while the lowest score is 55.00. The standard deviation is 8.92 with variance of 79.60 .

Table 4 The Statistical Scores of Vocabulary Knowledge

Statistics

\begin{tabular}{|c|c|c|}
\hline \multirow[t]{2}{*}{$\mathrm{N}$} & Valid & 80 \\
\hline & Missing & 0 \\
\hline \multicolumn{2}{|c|}{ Mean } & 72.6250 \\
\hline \multicolumn{2}{|c|}{ Median } & 75.0000 \\
\hline \multicolumn{2}{|c|}{ Mode } & $75.00^{\mathrm{a}}$ \\
\hline \multicolumn{2}{|c|}{ Std. Deviation } & 12.45816 \\
\hline \multicolumn{2}{|c|}{ Variance } & 155.206 \\
\hline \multicolumn{2}{|c|}{ Range } & 52.0 \\
\hline \multicolumn{2}{|c|}{ Minimum } & 40.00 \\
\hline \multicolumn{2}{|c|}{ Maximum } & 92.0 \\
\hline \multicolumn{2}{|c|}{ Sum } & 5810.00 \\
\hline
\end{tabular}

a. Multiple modes exist. The smallest value is shown

From the calculation of SPSS above, it can be seen that the mean score of vocabulary is 72.6 . The median score of vocabulary is 75.0 . The mode or the score that appears the most is 75.0. The highest score of the vocabulary test is 92.0 while the lowest score is 40.0. The standard deviation is 12.45 with variance 115.2 .

Table 5 Tests of Normality

Tests of Normality

\begin{tabular}{|l|r|r|r|r|r|r|}
\hline \multirow{2}{*}{} & \multicolumn{3}{|c|}{ Kolmogorov-Smirnov ${ }^{\mathrm{a}}$} & \multicolumn{3}{c|}{ Shapiro-Wilk } \\
\cline { 2 - 7 } & Statistic & \multicolumn{1}{|c|}{$\mathrm{df}$} & \multicolumn{1}{c|}{ Sig. } & Statistic & \multicolumn{1}{c|}{ df } & \multicolumn{1}{c|}{ Sig. } \\
\hline habit & .055 & 80 & $.200^{*}$ & .984 & 80 & .983 \\
\hline vocab & .088 & 80 & $.194^{*}$ & .976 & 80 & .135 \\
\hline
\end{tabular}

*. This is a lower bound of the true significance.

a. Lilliefors Significance Correction 
As the table above shows, the result of the distribution test is normal. Through the table of normality test, it was obtained a probability number/Asymp. Sig.(2-tailed). Satrio (2010) states that this percentage was compared with 0.05 $(\alpha=5 \%)$ to take the decision based on:

a. If Sig. $>0.05$, it means the data distribution is normal. b. If Sig. $<0.05$, it means the data distribution is not normal.

From the calculation of SaphiroWilk Method above, the Sig. value of Students' Habit is 0.200 while Sig. value of Vocabulary Knowledge is 0.194 . From the result, it can be concluded that the data of both variables have normal distribution because 0.200 and 0.194 are greater than 0.05 .

Table 6 The Linearity Test of the Data

\begin{tabular}{|c|c|c|c|c|c|c|c|}
\hline & & & Sum of Squares & df & Mean Square & $\mathrm{F}$ & Sig. \\
\hline \multirow[t]{5}{*}{ vocab * habit } & Between & (Combined) & 3362.066 & 16 & 210.129 & 4.523 & .000 \\
\hline & Groups & Linearity & 2663.103 & 1 & 2663.103 & 57.372 & .000 \\
\hline & & $\begin{array}{l}\text { Deviation from } \\
\text { Linearity }\end{array}$ & 698.963 & 15 & 46.598 & 1.003 & .464 \\
\hline & \multicolumn{2}{|c|}{ Within Groups } & 2926.621 & 63 & 46.454 & & \\
\hline & \multicolumn{2}{|l|}{ Total } & 6288.688 & 79 & & & \\
\hline
\end{tabular}

The table shows that the deviation from linearity is 0.464 . The data is categorized linear if the value of sig. is $0.464>0.05$. It means that there is a linear correlation between students' habit in watching English movies and their vocabulary knowledge.
Since the data distribution was normal and linear, for the next step, the writer was analyzed the correlation of students' habit in watching English movies and their vocabulary knowledge by using SPPS 23.00 program. 
Table 7. The Correlation between Students' Habit in Watching

English Movies and Their Vocabulary Knowledge

\begin{tabular}{|ll|r|r|}
\hline \multicolumn{2}{|c|}{ Correlations } \\
\hline vocab & Pearson Correlation & \multicolumn{1}{c|}{ vocab } & \multicolumn{1}{c|}{ habit } \\
& Sig. (2-tailed) & 1 & $.451^{\text {** }}$ \\
& $\mathrm{N}$ & 80 & .000 \\
\hline habit & Pearson Correlation & $.451^{* *}$ & 80 \\
& Sig. (2-tailed) & .000 & 1 \\
& $\mathrm{~N}$ & 80 & 80 \\
\hline
\end{tabular}

**. Correlation is significant at the 0.01 level (2-tailed).

The calculation above showed that Pearson correlation value is 0.451 and the sig (2-tailed) value is 0.001 . According to Priyatno (2009) stated that if the value of Sig. (2- tailed) lower than level of significance $(<0.05)$ it means that the correlation is at significant level. Therefore the Alternative Hypothesis (Ha) is accepted Therefore, the researcher concluded that there is a significant correlation between students' habit in watching English movies and their vocabulary knowledge and the correlation is positive since the coefficient 0.451 . Referring to the interpretation of correlation analysis by Arikunto (2012) which has been mentioned in the previous chapter, if the correlation value is between $0.4-0.6$ it can be confirmed that the two variables have a "moderate category".

The result of the research indicated that there is a positive and significant correlation between students' habit in watching English movies and vocabulary knowledge. A positive correlation means that the increase of students' habit of watching English movies is followed by the increase of vocabulary knowledge. The result of the hypothesis testing shows that the coefficient correlation between students' habit of watching English movies and vocabulary knowledge was 0.451 (sig. $0.000<0.05)$. This value is categorized into moderate correlation (Arikunto, 2012). As a result, the alternative hypothesis ( $\mathrm{Ha})$ is accepted and the null hypothesis (Ho) is rejected.

The coefficient of determination between students' habit in watching English movies and their vocabulary knowledge is $42 \%$. It means $42 \%$. Students' vocabulary knowledge is influenced by habit in watching English movies and $58 \%$ is influenced by other factors. From those data, it can be concluded that students' habit in watching 
English movies and their vocabulary knowledge of the second year English Department Universitas Riau is correlated and the level of correlation is at moderate category.

Moreover, these findings are in line with the previous studies done by Dahniar (2016) entitled "The Correlation between Student's Habit in Watching English Movie and Vocabulary Mastery at the Second Year SMAN 1 Anggeraja”. The result of his study was significant since the coefficient correlation is higher than the critical value of $\mathrm{r}$ table $(0.766>$ 0.339). Another study was conducted by

\section{CONCLUSIONS}

In this section, the researcher concluded the results based on the research question of this research. Firstly, it is shown that most of the students have a high habit of watching English movies. Secondly, most of them have good ability in vocabulary knowledge. In referring to the correlation analysis between both variables, the correlation coefficient (r) was 0.451 which is indicated as moderate correlation. Further, the contribution of variable students' habit in watching English movies and their vocabulary knowledge is about $42 \%$ and the rest $58 \%$ is caused by other factors.
Galant Jodhi Pratama (2015) "Correlation between Student's Habit in Watching English Movies and Their Vocabulary Size". The result of his study also indicated that there was a significant correlation between students' watching English movie habit and their vocabulary size. In short, the results of both studies indicate a significant positive correlation between two variables. There are two research findings that have advocated this study as well. Therefore, this research is relevant and supported by the two previous studies.

Finally, the researcher concluded that a significant correlation was discover ed between students' habit in watching English movies and their vocabulary knowledge of second year English Department Universitas Riau, and a moderate level correlation was found between both variables. Thus, it can be said that the habit in watching English movies was influenced by the acquisition of vocabulary knowledge because students were more enthusiastic and motivated to learn from the media. 


\section{ACKNOWLEDGMENTS}

Alhamdulillahirabbil'alamin. First of all, I am grateful to Allah subhanahu wata'ala, the Lord of the whole universe, the most Beneficent and most Merciful who has blesses and given the researcher abundant mercies, help and guides so that I could accomplish this thesis. Then, peace and salutation may be upon to the great messenger prophet Muhammad SAW, as our figure that has changed that era become sophisticated.

As one of the requirements that must be completed final project for undergraduate bachelor of degree in English Language Education, Teachers Training and Education Faculty (FKIP), Universitas Riau, It would not have been possible to write this thesis without the help and support of the kind people around.

\section{REFERENCES}

Arikunto, S. 2012. Dasar-Dasar Evaluasi Pendidikan. Jakarta: Bumi AksaraBaker, J., \& Westrup, H. (2003). Essential Speaking Skills: A Handbook for English Language Teachers. London: Continuum.

Azhar, A. 2011. Media Pembelajaran. Jakarta: Rajawali Pers.

Aziz, Firman., \& Fithry Fathiyyaturrizqi. 2017. Using Movie to Improve Students' Narrative. Advances in Social Science, Education and Humanities Research (ASSEHR), volume 82. Published by Atlantis Press.

Blasco et al.. 2015. Education through Movies: Improving teaching skills and fostering reflection among students and teachers.

Journal for Learning through the Arts. University of California. Permalink: http://escholarship.org/uc/item/2dt7s0zk.

Chayati, Selvi Nur. 2019. The Correlation Between Habit of Watching English Movie and Vocabulary Mastery Towards Listening Comprehension at the Eleventh Grade Students of SMKN 6 Surakarta in Academic Year 2018/2019. Surakarta: IAIN Surakarta.

Dahniar. 2016. The Correlation Between Student's Habit in Watching Movie and Vocabulary Mastery at the Second Year SMAN 1 Anggeraja. ETERNAL (English Teaching Learning and Research Journal) vol 2(1):110-121.

Darnton, Andrew. 2007. Habits, Routines and Sustainable Lifestyles, London: Department for Environment, Food and Rural Affairs.Published by the Department for Environment, Food and Rural Affairs: London. 
Dubray, C. 1910. Habit. In The Catholic Encyclopedia. New York: Robert Appleton Company. Retrieved March 8, 2020 from New Advent: http://www.newadvent.org/cathen/07099b.htm

Margono. 2010. The Effectiveness of teaching English Verbs (An Experimental study at the second grade students of SMP Negeri 18 Semarang in the Academic Year 2010/2011). Semarang: IAIN Walisongo Semarang.

Nawayanti, Renny. 2013. The effectiveness of touch and go game in teaching vocabulary (an experimental research with seventh grade students of SMP Askhabul Kahfi Semarang in the academic year of 2012/2013). Semarang: IAIN Walisongo.

Pratama, Galant Jodhi. 2015. Correlation between between Students' Habit in Watching English Movie and Their Vocabulary Size. U-JET:

Unila Journal of English Taching vol 4, No 9.

Priyatno, Dwi. 2009. Mandiri Belajar SPSS. Mediakom. Yogyakarta

Riandi. 2016 The effects of reading Habit and Vocabulary Mastery toward Student's Reading Comprehension in Serang City. Serang Banten:

Universitas Mathla'ul Anwar Banten.

Satrio, B. (2010). Modul Pelatihan SPSS (Aplikasi Pada Peneliatian Sosial). Lampung: Univerisitas Muhammadiyah Lampung.

Thornbury, S. 2002. How to Teach Vocabulary. Harlow: Pearson Education Limited.

Timotius. 2013. Improving Students Ability' In Vocabulary Mastery through Personal Vocabulary Notes. Unpublished Thesis. Pontianak: Tanjungpura University.

Yiwei, W. 2009. The Application of CLT in college English vocabulary teaching. Journal Of Cambridge Studies, 4 (3). 128-131. Linyi Normal University.

JEE ( Journal of English Education ) is licensed under a Creative Commons AttributionNonComercial-ShareAlike 4.0 International License.

JEE (Journal of English Education) Vol. 7 No. 1, June 2021

http://journal.upp.ac.id/index.php/JEE 